\title{
Seasonality, parity rates and transmission indices of Mansonella ozzardi (Manson) (Nematoda: Onchocercidae) by Cerqueirellum argentiscutum (Shelley \& Luna Dias) (Diptera: Simulidae) in a lower Solimões River community, Amazonas, Brazil ${ }^{1}$.
}

Jansen Fernandes de MEDEIROS ${ }^{2}$, Victor PY-DANIEL ${ }^{2}$

\begin{abstract}
Mansonella ozzardi is transmitted by two dipterian families, Ceratopogonidae (midges) and Simuliidae (black flies). In Brazil, black flies are vectors for this filariasis until now. In this paper, we determined the seasonality, parity capacity and parasitic infection rate of Cerqueirellum argentiscutum. The work was carried out in the Porto Japão community, Lower Solimões River, Amazonas, Brazil. Results show that the black flies were more abundant during the rainy season (from December to May). The number of parous flies was higher in every sampling during the course of year. Monthly Biting Rate (MBR $\left.123742.00, \mathrm{MBR}_{2} 86701.50\right)$ was high, although Parasitic Infection Rate (PIR $0.06, \mathrm{PIR}_{2} 0.08$ ) and Annual Transmission Potential (ATP 7.25) were low in numbers.
\end{abstract}

KEY WORDS

Simuliidae, Mansonella ozzardi, Amazônia, Brazil.

Sazonalidade, taxa de paridade e índices de transmissão de Mansonella ozzardi (Manson) (Nematoda: Onchocercidae) por Cerqueirellum argentiscutum (Shelley \& Luna Dias) (Diptera: Simuliidae) em uma comunidade do baixo rio Solimões, Amazonas, Brasil.

RESUMO

Mansonella ozzardi é transmitida por dois grupos distintos de insetos, Ceratopogonidae e Simuliidae. No Brasil, os simulídeos são os vetores dess a filariose. Neste trabalho, o objetivo foi determinar a sazonalidade, a paridade e a taxa de infecção parasitária de Cerqueirellum argentiscutum. O experimento foi realizado na comunidade Porto do Japão, Baixo rio Solimões, Amazonas, Brasil. Os simulídeos foram mais abundantes no período de chuva (dezembro a maio). Em todos os meses de coletas o número de paríparas foi maior. A taxa mensal de picada (TMP 123742.00, TMP $_{2}$ 86701.50) foi elevada, já a taxa de infecção parasitária (TIP ${ }_{1} 0.06, T_{2} P_{2}$ 0.08) e o potencial de transmissão anual (PTA 7.25) foram considerados baixos.

PALAVRAS-CHAVE

Simuliidae, Mansonella ozzardi, Amazônia, Brasil.

${ }^{1}$ This work is part of the first author's PhD Thesis

${ }^{2}$ Instituto Nacional de Pesquisas da Amazônia, Coordenação de Pesquisas em Ciências da Saúde, Laboratório de Filarioses e Vetores, C.P. 478, 69011970, Manaus, AM, Brasil, E-mail: jmedeiro@inpa.gov.br, pydaniel@inpa.gov.br 


\section{ACTA \\ AMAZONICA}

SEASONALITY, PARITY RATES AND TRANSMISSION INDICES OF MANSONELLA OZZARDI (MANSON) (NEMATODA: ONCHOCERCIDAE) BY CERQUEIRELLUM ARGENTISCUTUM (SHELLEY \& LUNA DIAS) ...

\section{INTRODUCTION}

Mansonella ozzardi is the filarial agent of mansonelliasis. The first report of this disease was made by Manson in 1897, in Guiana. According to Batista et al. (1960) and Oliveira (1961), people infected with mansonelliasis and high microfilaremia present symptoms of moderate fever, articular pain, adenite (followed by dizziness) and headaches. A new sintomatology attributed to this filariasis is the occurrence of visual lesions, which in turn can lead to blindness (Branco et al., 1998, Garrido \& Campos, 2000).

This filariasis is found from Mexico to Argentina, Guatemala and Panama in Central America, and also some islands of the Antillean archipelago. Except for Chile, Uruguay and Paraguay, every country in South America has already reported the presence of this parasite (Tavares \& Fraiha Neto, 1997).

M. ozzardi is transmitted by insects of the families Ceratopogonidae and Simuliidae, Diptera. Initial work accomplished by Buckley (1934) indicated Culicoides furens (Poey) (Ceratopogonidae) as the vector of M. ozzardi in St Vincent Island, Caribbean. C. furens was later revealed as a vector in Mexico and Trinidad (Biagi et al., 1958), whereas C. pblebotomus (Williston) was the vector in Haiti (Nathan, 1978, Lowrie \& Raccurt, 1981).

In Colombia, Simulium sanguineum [ = Cerqueirellum sanguineum $(\mathrm{Knab})]$, S. amazonicum $[=$ C. amazonicum (Goeldi)], S. argentiscutum [ = C. argentiscutum (Shelley \& Luna Dias)] and Culicoides insiniatus Ortiz \& Leon have been reported as likely vectors of $M$. ozzardi (Tidwell et al., 1980, Tidwell \& Tidwell, 1982). S. sanguineum $[=C$. sanguineum (Knab)], S. minusculum [= Psaroniocompsa incrustata (Lutz) ] and S. sanchezi $[=$ C. oyapockense (Floch $\&$ Abonnenc)] were indicated as vectors of $M$. ozzardi in south Panama, Guyana and Venezuela, respectively (Nathan et al., 1982, Peterson et al., 1984, Yarzábal et al., 1985). Shelley \& Coscarón (2001) observed in S. exiguum [= Notolepria exiguua (Roubaud)] and Culicoides labillei (Iches) the microfilarial development of $M$. ozzardi to the infective stage $\left(\mathrm{L}_{3}\right)$ in (northern) Argentina.

Early assessment by Cerqueira (1959) indicated $S$. amazonicum $[=C$. amazonicum $]$ as a vector of $M$. ozzardi in Brazil. However, Moraes et al. (1985) suggested that the species identified in that work was probably $S$. argentiscutum $[=C$. argentiscutum $]$. Shelley \& Shelley (1976) also reported S. amazonicum [= C. amazonicum] as a vector of $M$. ozzardi, while Shelley et al. (1980) indicated not only $S$. amazonicum $[=C$. amazonicum $]$, but also $S$. argentiscutum [ $C$. argentiscutum $]$ involvement in the transmission of mansonelliasis. Moraes et al. (1985) indicated S. oyapockense [= C. oyapockense] as a vector in the State of Roraima, Brazil.

In Brazil, the first report of $M$. ozzard $i$ was made by Deane (1949). Lacerda \& Rachou (1956) provided evidence that this filaria is found in the State of Amazonas, in the communities bordering the Solimões River and its tributaries.
The goal of this work is to assess the seasonality, the parity and the transmission indices of $C$. argentiscutum one of the vectors of $M$. ozzardi in Brazil. This is the first work considering the range of a 1-year sampling of $C$. argentiscutum. This work follows the nomenclature according to Py-Daniel \& Moreira Sampaio (1994), where the subgenus is elevated to genus level in Simuliidae.

\section{MATERIALS AND METHODS}

\section{Study area}

This work was conducted from September 1999 to August 2000, in the Porto Japão community (3³4" S / $61^{\circ} 09^{\prime \prime}$ W), lower Solimões River, Amazonas, Brazil. The community has approximately 100 people, subsisting on fishing, hunting and farming.

\section{Procedure of Capture}

The black flies were collected monthly during four consecutive days starting at 6:00 and ending at 18:15. The sampling intervals were divided into 15-minute periods, each followed by 15-minute intervals. They were captured by a laboratory technician, using manual suction collectors, according to the methodology of Medeiros \& Py-Daniel (1999) and Medeiros \& Py-Daniel (2003).

\section{Analysis of the Ovaries}

Between samplings, we analysed the ovaries to verify whether the females were nulliparous or parous, according to the methodology of Ramirez-Perez (1977). The flies were then placed in tubes containing $70 \%$ ethanol, for later examination at the Laboratório de Filarioses e Vetores of the Instituto Nacional de Pesquisas da Amazônia, Manaus, Brazil.

\section{Dissection of the black flies}

The flies were immersed in acid hematoxilin and stained for a period of 48 hours, prior to dissection under a stereomicroscope. They were placed on a slide, divided in three parts (head, thorax and abdomen), placed in a drop of a glycerin and covered by a coveslip. The slides were then observed by light microscopy, and the flies were verified for mansonelliasis infections. When the parasites were found, the developmental stages (mf, L1, L2, L3) were identified according to the method of Yarzábal et al. (1985).

\section{Parasitic Infection Rate (PIR)}

Two methods were used to obtain this index: PIR, considered the number of females infected by any filarial stage (mf, L1, L2 and L3) of $M$. ozzardi divided by the number of parous females 


\section{ACTA \\ AMAZONICA}

SEASONALITY, PARITY RATES AND TRANSMISSION INDICES OF MANSONELLA OZZARDI (MANSON) (NEMATODA: ONCHOCERCIDAE) BY CERQUEIRELLUM ARGENTISCUTUM (SHELLEY \& LUNA DIAS) ... and dissected nulliparous X 100; $\mathrm{PIR}_{2}$ considered the number of females infected with any filarial stages, except microfilaria (L1, L2 and L3) of M. ozzardi divided by the number of parous females dissected X 100 (Py-Daniel et al., 2000).

\section{Monthly Biting Rate (MBR)}

This index estimates the number of black flies that bite a person exposed in the same place for a month, subjected to bites all day long (Davies \& Crosskey, 1991). Two ways of calculating MBR were taken into account: one considers the total of captured females (nulliparous + parous) while the other considers only the parous females (Py-Daniel et al., 2000).

$$
\mathrm{MBR}_{1}=\frac{\begin{array}{c}
\text { Total number of females caught } \\
\mathrm{X} \mathrm{N} \mathrm{N}^{0} \text { of days in a month }
\end{array}}{\text { Number of catching days }}
$$

$$
\mathrm{MBR}_{2}=\frac{\begin{array}{c}
\text { Total number of parous females caught } \\
\mathrm{X} \mathrm{N} \text { of days in a month }
\end{array}}{\text { Number of catching days }}
$$

\section{Monthly Transmission Potential (MTP)}

This index estimates the number of L3 stage larvae that can be transmitted to a person exposed to the vector during a one month period (Duke, 1968, Davies \& Crosskey, 1991).

$$
\text { MTP }=\frac{\text { MBR }_{1} \text { X Number of L3 stage larva by black flies }}{\text { Total number of black flies dissected }}
$$

\section{Annual Transmission Potential (ATP)}

represents the number of $\mathrm{L} 3$ stage larvae that can be transmitted to a person exposed to the vector during a one year period (Davies \& Crosskey, 1991). It is calculated by the sum of all MTPs (Monthly Potential Transmission) (PyDaniel et al., 2000).

\section{Prevalence}

Approximately $80 \%$ of the habitants in Porto Japão were examined. A lancet was used to puncture the fourth finger of individuals and a drop of blood was used to make a thick film on a microscope slide. The film was dehaemoglobinized, fixed in $80 \%$ methanol, and later stained with Giemsa and examined for microfilariae.

\section{Additional Information}

Ribeiro \& Adis (1984) consider two seasons for the Central Amazon, a dry season between June and November and a rainy season from December to May.
The statistical analyses were performed as nonparametric tests, using the Mann-Whitney (U-test).

\section{RESULTS}

\section{Seasonality}

16320 C. argentiscutum females were collected throughout this work, with an average of 1360 individuals per month and 340 individuals per day. The highest number of simuliid flies was obtained during the rainy season (from December to May), with 13488 (82.65\% of the total collected flies) $(2248 \pm 1373.9$ flies/month $/$ $562 \pm 366.3$ flies/day), showing a statiscally significant difference $(\mathrm{U}=325 \mathrm{P}<0.001)$ in relation to the number of flies collected in the dry season (from June to November) with a total of 2832 individuals (472 \pm 305.4 flies/month / $118 \pm 86.3$ flies/day), approximately $17.35 \%$ of the total (Table 1).

During the rainy season, the highest incidence of simuliid flies was reported from December 1999 to February 2000, resulting in a total of 9753 specimens (59.76\% of the total/year), (3251 \pm 1290.2 flies/month / $813 \pm 363$ flies/day). In the dry season, the highest number of black flies was obtained in September/1999, November 1999 and June 2000, resulting in a total of 1994 individuals $(8.53 \%$ of the total/year) $(664.6 \pm 306$ flies/month / $166.1 \pm 94$ flies/day).

The highest number of individuals was collected in January (1021.5 \pm 239.3 flies/day), corresponding to approximately $25 \%$ of the total. The lowest number of individuals was sampled in July $(23 \pm 18.3$ flies/day), corresponding to approximately $0.56 \%$ of the total flies collected throughout this study.

\section{Ovarian physiological stage}

A total of 11441 parous females (70.1\%) and 4879 nulliparous females (29.9\%) were collected. The abundance of parous flies over the nulliparous flies was verified in every month of the year (Figure 1).

\section{Parasitic Infection Rate - PIR}

Only nine out of the 16.320 collected flies were infected by $M$. ozzardi, representing a Parasitic Infection Rate $\left(\mathrm{PIR}_{1}\right.$ ) of $0.06 \%$, and a PIR of $0.08 \%$. The highest number of infected simuliid flies was found in January and February. The highest PIRs was reported in July (Table 2).

A total of $34 \mathrm{M}$. ozzardi larval stage was found in the black flies collected, with a higher number of L2 stage (17), followed by L1 (16) and L3 (1). All the larval stages of $M$. ozzardi were found in the thorax of the flies. 


\section{ACTA \\ AMAZONICA}

SEASONALITY, PARITY RATES AND TRANSMISSION INDICES OF MANSONELLA OZZARDI (MANSON) (NEMATODA: ONCHOCERCIDAE) BY CERQUEIRELLUM ARGENTISCUTUM (SHELLEY \& LUNA DIAS) ...

\section{Monthly Biting Rates - MBR, Monthly Transmition Potential - MTP and Annual Transmission Potential - ATP}

The estimated Monthly Biting Rate $\left(\mathrm{BMR}_{1}\right)$ was 124.521,25 bites/person-month and $\mathrm{BMR}_{2}$ was $87.348,75$. Both $\mathrm{BMR}_{1}$ and $\mathrm{BMR}_{2}$ were higher in January $(31.674,25)$ and February $(30.232,75)$ while lower BMRs were reported in July $(690,0)$ and August $(2.549,75)$ (Table 2).

The MTP was only calculated for February, when a L3 stage was found in an infected black fly. Therefore, the calculated MTP has the same value as the ATP, i. e., 7.25 (Table 2).

\section{DISCUSSION}

The lowest number of flies collected in July was due to a cold mass movement in the first two days of sampling, when strong winds (up to $22,4 \mathrm{Km} / \mathrm{h}$ ) were verified in the area, followed by low temperatures and high relative air humidity.

Our results agree with statements of the local population where the work was carried out, corroborating the fact that the highest number of black flies occur in months of higher precipitation. Cerqueira (1959) in a work developed in the city of Codajás (Middle Solimões River), Amazonas, the largest density of $S$. amazonicum $[=C$. argentiscutum $]$ was also found during the rainy season, considered by him to be from January to June.

Medeiros \& Py-Daniel (1999) verified a higher abundance of the species $C$. oyapockense, in Xitei/Xidea, in the Yanomami indigenous area, Roraima, Brazil, in the period of higher precipitation. Shelley (1988) working in Toototobi and Shelley

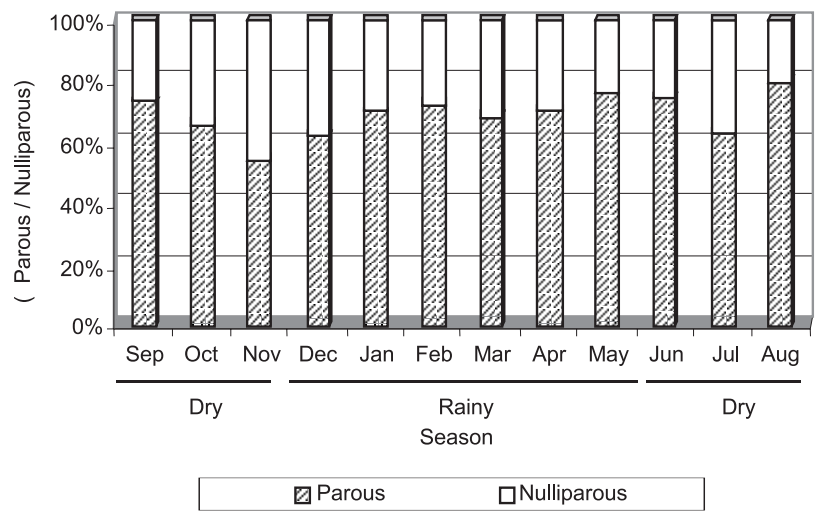

Figure 1 - Distribution of the Cerqueirellum argentiscutum females according to the physiologic ovarian condition (parous or nulliparous), collected from September/1999 to August/2000, in Porto Japão, Amazon, Brazil.

et al. (1997), in Catrimani (both Yanomami areas) reported that the highest number of $S$. oyapockense $[=C$. oyapockense] was observed during the rainy period.

The present results provided evidence that $C$. argentiscutum was more abundant in the beginning of the rainy season (from December to February), subsequently decreasing in numbers from March to May, and at the beginning of the dry period (June and July) when the Solimões River is flooded. We observed that from May to July, when the floods reached the forest, the populations of $C$. argentiscutum migrated to the inundated area (also called várzea), where a higher prevalence of the simuliids were found, correlated with a

Table 1 - Seasonal distribution of Cerqueirellum argentiscutum biting females in four days of monthly collections, from September/ 1999 to August/2000, in Porto Japão community, Amazonas, Brazil.

\begin{tabular}{lccccccccc}
\hline \hline Month/Day & Period & I & II & III & IV & Total & \% & \multicolumn{2}{c}{$\begin{array}{c}\text { Mean/Day } \pm \text { SD } \\
\mathrm{n}=04\end{array}$} \\
\hline September/99 & Dry & 233 & 284 & 115 & 386 & 1018 & 6.24 & 254.5 & \pm 112.6 \\
October & Dry & 96 & 67 & 136 & 118 & 417 & 2.56 & 104.3 & \pm 29.7 \\
November & Dry & 203 & 105 & 116 & 67 & 491 & 3.01 & 122.8 & \pm 57.4 \\
December & Rainy & 342 & 848 & 403 & 172 & 1765 & 10.81 & 441.3 & \pm 288.2 \\
January/00 & Rainy & 1119 & 1312 & 867 & 789 & 4087 & 25.04 & 1021.8 & \pm 239.3 \\
February & Rainy & 847 & 724 & 1028 & 1302 & 3901 & 23.90 & 975.3 & \pm 251.0 \\
March & Rainy & 442 & 364 & 204 & 441 & 1451 & 8.89 & 362.8 & \pm 111.9 \\
April & Rainy & 284 & 124 & 422 & 326 & 1156 & 7.08 & 289.0 & \pm 124.2 \\
May & Rainy & 286 & 244 & 428 & 170 & 1128 & 6.91 & 282.0 & \pm 108.5 \\
June & Dry & 103 & 95 & 145 & 142 & 485 & 2.97 & 121.3 & \pm 25.9 \\
July & Dry & 12 & 03 & 36 & 41 & 92 & 0.56 & 23.0 & \pm 18.3 \\
August & Dry & 109 & 59 & 75 & 86 & 329 & 2.02 & 82.3 & \pm 20.9 \\
\hline Total & & 4076 & 4229 & 3975 & 4040 & 16320 & 100.00 & 4080.0 & \pm 107.7 \\
\hline \hline
\end{tabular}




\section{ACTA \\ AMAZONICA

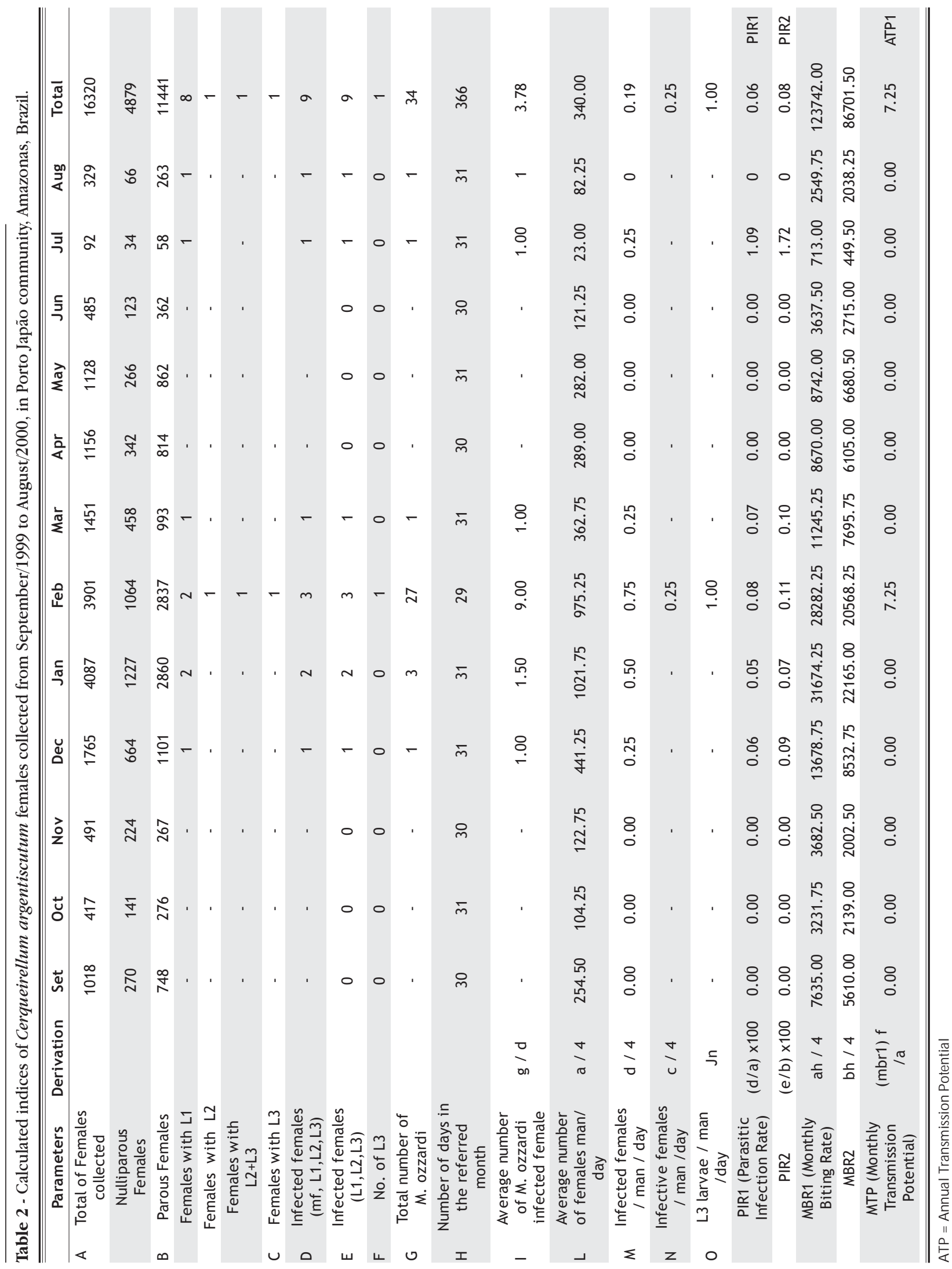




\section{ACTA \\ AMAZONICA}

SEASONALITY, PARITY RATES AND TRANSMISSION INDICES OF MANSONELLA OZZARDI (MANSON) (NEMATODA: ONCHOCERCIDAE) BY CERQUEIRELLUM ARGENTISCUTUM (SHELLEY \& LUNA DIAS) ... decrease in the number of specimens sampled alongside the river. It may be suggested that females of this species migrate to the várzea area as a survival strategy, to have access to other sources of blood.

The high number of parous flies collected in this work is probably related to the anthropophilic behavior of $C$. argentiscutum and their high chances of finding a host (man), taking into account the working habits of the local people (setting up agricultural crops at the margins of the river, being exposed daily to the biting activity of this species). Medeiros \& Py-Daniel (1999) found $84 \%$ of parous female of C. oyapockense in Xitei/Xidea; and Shelley et al. (1997), collected a higher number of $S$. oyapockense $[=C$. oyapockense $]$ parous females (79.3\%) as compared to the nulliparous females $(20.7 \%)$ in Toototobi.

In a previous report involving several streams in the city of Codajás, Cerqueira (1959) indicated for S. amazonicum [ $=C$. argentiscutum $]$ a distinctive parasitic infection rate for the various places, totaling $18.5 \%$ of the 1367 individuals captured. Shelley \& Shelley (1976) found a natural infection rate for $S$. amazonicum [= C. amazonicum] estimated in $0.99 \%$, representing 35 individuals out of 3530 collected in humans and bovine cattle, while working in two villages located on the Purus River, close to the municipality of Lábrea, Amazonas. Shelley et al. (1980) found S. amazonicum $[=$ C. amazonicum $]$ and Simulium n.sp [= C. argentiscutum ] naturally infected with $M$. ozzardi, with a parasitic infection rate of $3.1 \%$ and $9.7 \%$, respectively (Ticuna tribe, Solimões River, Amazonas).

By comparing the Parasitic Infection Rates (PIR) of the published works cited above, we can say that the PIR values observed in this work are low, particularly in relation to the findings of Cerqueira (1959) and Shelley et al. (1980). The low rates (PIR and PIR $_{2}$ ) found in this work are probably due to the of absence of mansonelliasis in the community of Porto Japão ( $0 \%$ prevalence, in $80 \%$ of the examined population). The black flies found infected are most likely to be related to factors such as periodic visits (migrations) of people infected with mansonelliasis from other communities located in the Middle and Upper Solimões River, considering the fact that daily movement of ships takes place on the river.

In Brazil, reports on the $M$. ozzardi vectors have not been considering systematic collection (Cerqueira, 1959, Shelley \& Shelley, 1976, Shelley et al., 1980, Moraes et al., 1985), and therefore, for comparisons of the Monthly Biting Rate (MBR), we considered some works on species involved in the transmission of the filarial worm Onchocerca volvulus (Leuckart) in the indigenous Yanomami area, Roraima, Brazil (Andreazze \& Py-Daniel, 1999, Py-Daniel et al., 2000).

Andreazze \& Py-Daniel (1999) in the Xitei/Xidea area, determined a $\mathrm{MBR}_{1}$ of 63.079,7 and a MBR of 37.394,5 for the species $P$. incrustata. Py-Daniel et al. (2000) found a $\mathrm{MBR}_{1}$ of 28.443,0 and a MBR of 18.360,2 in a work conducted in the same place with the species T. guianense. Py-Daniel et al. (2000) also estimated the MBR for the four species (P. incrustata, T. guianense, C. oyapockense and $N$. exiguua) occurring in Xitei/Xidea, and found a MBR of 92.931,7 and $\mathrm{MBR}_{2}$ of 56.936,5.

By comparing the MBRs between these two areas (Porto Japão and Xitei/Xidea), we observed that in Porto Japão, MBRs in only one species was higher than the total MBRs calculated for the four species of Xitei/Xidea area. Therefore, the species C. argentiscutum, in some periods of the year, such as January and February, represents a plague for the population living alongside the Solimões River due to the high density of flies and consequently, the discomfort of their bites.

The fact that only one metacyclic larva (L3 stage) was found in February indicates a low ATP for this area, suggesting that a low transmission risk of $M$. ozzardi exists for the population of the study area. According to an index established by the World Health Organization for the vectors of $O$. volvulus, the estimated level in order to maintain transmission is around $100 \mathrm{~L} 3$ larvae per person during one year (Davis et al., 1994), which is not yet known for $M$. ozzard $i$ vectors.

\section{ACKNOWLEDGEMENTS}

We thank INPA for support, CNPq for the PhD scholarship for the first author, and the Porto Japão community, especially Mr. Aníbal César B. Lima for excellent assistance in the black fly samplings and dissections.

\section{LITERATURE CITED}

Batista, D; Oliveira, W.R.; Rabello, V.D. 1960. Estudo da patogenicidade da Mansonella ozzardi e da sintomatologia da mansonelose. Revista do Instituto de Medicina Tropical de São Paulo, 2(5): 281-289.

Biagi, F.; Tay, J.; Biage, A.M. 1958. Observaciones sobre mansonelosis en la Peninsula de Yucatán. V. Culicoides furens como transmissor. Medicina 38: 377-379.

Branco, B.C.; Chamon, W.; Belfort, R.N.; Belfort, Jr.R.; Costa, A.J.A. 1998. Achados oculares entre habitantes do município de Pauiní e possível associação entre lesões corneanas e mansonelose na Amazônia. Arquivo Brasileiro de Oftalmologia, 61(6): 675-681.

Buckley, J.J.C. 1934. On the development, in Culicoides furens Poey, of Filaria (=Mansonella) ozzardi Manson, 1897.Journal Helmintbologia, 12: 99-118.

Cerqueira, N.L. 1959. Sobre a transmissão da Mansonella ozzardi $1^{\mathrm{a}} \mathrm{e} 2^{\mathrm{a}}$ notas (Trabalho do Inpa).Jornal Brasileiro de Medicina, I(7): 885-914.

Davies, J.B.; Crosskey, R.W. 1991. Simulium - Vectors of Onchocerciasis. World Health Organization, 109 pp.

Davis, J.R.; Wasserman, S.S.; Trpis, M. 1994. Diurnal biting activity and transmission of Onchocerca volvulus (Filariata, Onchocercidae) by Simulium yabense (Diptera: Simuliidae) in Liberia. Journal Medical Entomology, 31(2): 217-224 


\section{ACTA AMAZONICA}

Deane, M.P. 1949. Sobre a incidência de filárias humanas em Manaus Estado do Amazonas. Revista do Sesp, 2(3): 849-858.

Duke, B.O.L. 1968. Studies on factors influencing the transmission of Onchocerciasis IV. The biting-cycles, infective biting density and transmission potential of 'forest' Simulium damnosum. Annals of Tropical Medecine Parasitology, 62: 95-106.

Garrido, C.; Campos, M. 2000. First of presumed parasitic keratitis in indians from the Brazilian Amazon. Cornea, 19(6): 817-819.

Lacerda, N.B.; Rachou, R.G. 1956. Filarioses humanas nas sedes municipais do Estado do Amazonas e dos Territórios do Acre, Guaporé e Rio Branco. Revista de Malariologia e Doenças Tropicais, 8(3): 437-442.

Lowrie, R.C.Jr.; Raccurt, C. 1981. Mansonella ozzardi in Haiti II. Arthropod vector studies. American Journal Tropical Medicine and Hygiene, 70: 16-17.

Medeiros, J.F.; Py-Daniel, V. 1999. Atividade hematófagica e infecção natural de três espécies de Simuliidae (Diptera: Culicomorpha) em Xitei/Xidea, área indígena Yanomami, Roraima, Brasil. Entomologia y Vectores, 6(3): 210-226.

Medeiros, J.F.; Py-Daniel, V. 2003. Estado fisiológico e preferência de picadas de Cerqueirellum argentiscutum (Shelley \& Luna Dias, 1980) (Diptera: Simuliidae), vetor de Mansonella ozzardi (Manson, 1897) (Nematoda: Onchocercidae) no Brasil. Entomologia y Vectores, 9(4): 505-517.

Moraes, M.A.P.; Shelley, A.J.; Luna Dias, A.P.A. 1985. Mansonella ozzardi no Território Federal de Roraima. Distribuição e achado de um novo vetor na área do rio Surumu. Memórias do Instituto Oswaldo Cruz, 80(4): 395-400.

Nathan, N.B. 1978. Culicoides phlebotomus, a vector on M. ozzardi in coastal North Trinidad West Indies. Transaction Royal Society of Tropical Medicine and Hygiene, 72: 436-437.

Nathan, M.B.; Tikasingh, E.S.; Munroe, P. 1982. Filariasis in amerindians of western Guyana with observations on transmission of Mansonella ozzardi by a Simulium species of the amazonicum group. Tropenmedizin Parasitologie, 33: 219-222.

Oliveira, W.R. 1961. Filarioses humanas na cidade de Manaus. $O$ Hospital, 56(2): 301-303.

Peterson, J.L.; Bawden, M.P.; Wignell, F.S.; Latorre, C.R.; Johnson, C.M.; Miranda, C. 1984. Mansonella ozzardi en el Darien (Panama). Revista Médica Panama, 9: 236-246.

Py-Daniel, V.; Andreazze, R.; Medeiros, J.F. 2000. Projeto Piloto Xitei/Xidea, (Roraima). I - índices epidemiológicos da transmissão de Onchocerca volvulus (Leuckart, 1893) para os anos de 1995-1996. Entomologia y Vectores, 7(4): 389-444.

Py-Daniel, V.; Moreira-Sampaio RT 1994. Jalacingomyia Gen. (Culicomorpha); A ressurreição de Gymnopaidinae; a eliminação do nível tribal, Apresentação de novos caracteres e a redescrição dos estágios larval e pupal de Simulium colombaschense (Fabricius, 1787) (Diptera, Simuliidae). Memorias del Caicet, IV(1,2): 101-148.
Ramírez-Perez, J. 1977. Estudo sobre la morfologia de Simulium metallicum vector de la Oncocercosis humana en Venezuela. Organizacion Panamericana de la Salud/Organizacion Mundial de la salud, Publicación Científica $\mathrm{N}^{0} 338$, iii +1 -140 pp.

Ribeiro, M.N.G.; Adis, J. 1984. Local rainfall variability - a potential bias for bioecological studies in the Central Amazon. Acta Amazonica, 14(1-2): 159-174.

Shelley, A.J. 1988. Vector aspects of the epidemiology of Onchocerciasis in Latin America. Annual Review of Entolomogy 30: 337-336.

Shelley, A.J.; Coscarón, S. 2001. Simuliid blackflies (Diptera: Simulidae) and ceratopogonid Midges (Diptera: Ceratogonidae) as vectors of Mansonella ozzardi (Nematoda: Onchocercidae) in northern Argentina. Memórias do Instituto Oswaldo Cruz 96(4): 451-458.

Shelley, A.J.; Lowry, C.A.; Maia-Herzog, M.; Luna Dias, A.P.A.; Moraes, M.A.P. 1997. Biosystematic studies on the Simuliidae (Diptera) of the Amazonia Onchocerciasis focus. Bull British Museum (Natural History) Entomology, 66(1): 1-121.

Shelley, A.J.; Luna Dias, A.P.A.; Moraes, M.A.P. 1980. Simulium species of the amazonicum group as vectors de Mansonella ozzardi in the Brazilian Amazon. Trans Royal Society of Tropical Medicine Hygiene, 74: 784-788.

Shelley, A.J.; Shelley, A. 1976. Further evidence for the transmission of Mansonella ozzardi by Simulium amazonicum in Brazil. Annals Tropical Medical Parasitology, 70: 213-217.

Tavares, A.M.; Fraiha Neto, H. 1997. Mansonelose. In: Queiroz de Leão, R.N.(Ed). Doenças Infecciosas e Parasitárias, Enfoque Amazônico, p. 733-737.

Tidwell, M.A.; Tidwell, M.A.; Muñoz de Hoyos, P. 1980. Development of Mansonella ozzardi in blackflies of the Simulium sanguineum group from eastern Vaupés, Colombia. American Journal of Tropical Medicine and Hygiene, 29: 1209-1214.

Tidwell, M.A.; Tidwell, M.A. 1982. Development of Mansonella ozzardi in Simulium amazonicum, S. argentiscutum and Culicoides insinuatus from Amazonas, Colombia. American Journal Tropical Medicine Hygiene, 3: 1137-1141.

Yazarbal, L.; Basáñez, M.G.; Ramírez-Pérez, J.; Ramírez, A.; Botto, C.; Yazarbal, A. 1985. Experimental and natural infection of Simulium sanchezi by Mansonella ozzardi in the middle Orinoco region of Venezuela. Transactions Royal Society of Tropical Medecine Hygiene, 79: 29-33.

\section{RECEBIDO EM 23/01/2004 ACEITO EM 19/04/2004}


